\title{
Amitraz Poisoning: An Emerging and yet Underestimated Poison-A Review
}

\author{
Sidhant Sachdeva ${ }^{1}$, Gurinder Mohan ${ }^{2}$, Parminder Singh ${ }^{3}$
}

\begin{abstract}
Background: Amitraz is a member of the formamidine family of pesticides. Its structure is 1,5 di-(2,4-dimethylphenyl)-3-methyl-1,3,5-triazapenta1,4-diene. It is used as an agricultural insecticide for fruit crops and as an acaricide for dogs and livestock. Awareness about amitraz, its toxicity, and its management remains poor among physicians, which is probably the reason for underreporting of amitraz intoxication in remote rural areas. In this systematic review on amitraz intoxication, we focus on demographics, toxicokinetics, mechanisms of toxicity, clinical features, and treatment modalities in amitraz poisoning.

Materials and methods: EmBase and Medline databases were searched for the following terms:"amitraz,"'intoxication,"'"poisoning," and "toxicity." Case reports, case series, and original articles describing human cases of amitraz poisoning were included.

Results: A total of 251 articles were retrieved after excluding citations common to the two databases. A total of 63 articles described human cases. The clinical manifestations varied from central nervous system (CNS) depression (drowsiness, coma, and convulsions), miosis or mydriasis, respiratory depression, bradycardia, hypotension, hyperthermia or hypothermia, hyperglycemia, polyuria, vomiting, and reduced gastrointestinal motility. Only six reported deaths have been reported (case fatality rate, 1.9\%). The proposed lethal dose of the toxin was reported to be 200 $\mathrm{mg} / \mathrm{kg}$. Around $33 \%$ of patients developed respiratory failure and $20 \%$ of them needed mechanical ventilation.

Interpretation and conclusion: Amitraz poisoning occurs in either accidental or suicidal manner and is more common in children than adults. There is no specific antidote for this toxin till date. It has an excellent prognosis with supportive management.

Keywords: Amitraz, Organophosphate/carbamate, Poison.

AMEl's Current Trends in Diagnosis \& Treatment (2020): 10.5005/jp-journals-10055-0085
\end{abstract}

\section{INTRODUCTION}

Amitraz is a member of the formamidine family of pesticides. Its structure is 1,5 di-(2,4-dimethylphenyl)-3-methyl-1,3,5-triazapenta1,4-diene. It is used as an agricultural insecticide for fruit crops and as an acaricide for dogs and livestock. ${ }^{2}$ It is most commonly marketed as a $12.5-50 \%$ aqueous solution and has to be diluted in water in 1:100-1:1000 ratio before use. ${ }^{3,4}$ In most of the preparations, xylene is used as a solvent. Tetrachloroethylene and mixtures of petroleum products containing predominantly aromatic hydrocarbons ${ }^{5}$ are the other solvents commonly used. It is classified as "Class III-slightly toxic" and a group C "possible" human carcinogen. ${ }^{6}$ The first human case of poisoning was reported in $1983 .{ }^{7}$

Amitraz is available without a physician's prescription in all leading chemist shops under variety of trade names. In India, the most common brand name is "Ridd."

Amitraz is pharmacologically active with an alpha-2-agonist action. The stimulatory effect on alpha 2 receptors is mainly responsible for neurotoxic and proconvulsant effects. It also acts by inhibiting MAO activity and PGE2 synthesis. Amitraz poisoning commonly occurs through oral or dermal routes and potentially by inhalation. The clinical manifestations vary from central nervous system (CNS) depression (drowsiness, coma, and convulsions), miosis or mydriasis, respiratory depression, bradycardia, hypotension, hyperthermia or hypothermia, hyperglycemia, polyuria, vomiting, and reduced gastrointestinal motility.

Awareness about amitraz, its toxicity, and its management remains poor among physicians, ${ }^{5}$ which is probably the reason for underreporting of amitraz intoxication in remote rural areas. Also, it is commonly confused with organophosphate/carbamate (OPC) poisoning. ${ }^{5,8}$ India has reported several cases over the past few
${ }^{1-3}$ Department of Medicine, Sri Guru Ram Das University of Health Sciences and Research, Amritsar, Punjab, India

Corresponding Author: Gurinder Mohan, Department of Medicine, Sri Guru Ram Das University of Health Sciences and Research, Amritsar, Punjab, India, Phone: +91 9815341556, e-mail: drgurinder1968@gmail. com

How to cite this article: Sachdeva S, Mohan G, Singh P. Amitraz Poisoning: An Emerging and yet Underestimated Poison-A Review. AMEl's Curr Trends Diagn Treat 2020;4(1):21-25.

Source of support: Nil

Conflict of interest: None

years. ${ }^{9-11}$ Review articles on amitraz have also been published by Yilmaz and Yildizdas ${ }^{12}$ and Proudfoot. ${ }^{13}$ In this systematic review on amitraz intoxication, we focus on demographics, toxicokinetics, mechanisms of toxicity, clinical features, and treatment modalities in amitraz poisoning.

\section{Materials and Methods}

EmBase and Medline databases were searched for the following terms: "amitraz," "intoxication," "poisoning," and "toxicity." Case reports, case series, and original articles describing human cases of amitraz poisoning were included. A total of 251 articles were retrieved after excluding citations common to the two databases. A total of 63 articles described human cases.

Twenty articles were excluded as four were abstracts,, ,14-16 due to insufficient clinical details of $\operatorname{cases}^{17-20}$ and articles that were published in a language other than English. The search hence yielded 41 articles. ${ }^{1,3-5,7-12,22-43}$ 


\section{Initial Review of Studies}

The initial database generated from the electronic searches was compiled and the full text of each selected citation was obtained and reviewed in detail.

\section{Data Abstraction}

The data collected were recorded on a standard data extraction form. The following items were extracted: (1) publication details (title, authors, and year of publication); (2) route (oral, dermal, or other) and manner (accidental, suicidal, and therapeutic misadventure) of poisoning; (3) country; (4) females and children ( $\leq 13$ years of age) reported in the study; (5) time of onset of symptoms; (6) quantity of poison consumed; (7) signs and symptoms reported; (8) inotropic support, mechanical ventilation, and specific treatment (gastric lavage, activated charcoal, atropine, and others) offered to patients; (9) extubation or weaning, discharge from ICU or hospital, and recovery of sensorium; and (10) death.

\section{Results \\ Epidemiology}

A majority (56.5\%) of the patients were children and there was no gender predilection ( $51.3 \%$ males and $48.7 \%$ females) among the cases. The commonest route of exposure to the poison was by ingestion (91.9\%) followed by the percutaneous route $(7.4 \%)$ and rarely by inhalation and intravenous injection of the toxin. ${ }^{26,35}$ The manner of poisoning was accidental $(56.5 \%)$ in the majority followed by suicidal ingestion (30\%). Few (16) patients had intentional percutaneous exposure as in some regions in Turkey, amitraz had been used to treat scabies and pediculosis in humans. ${ }^{37}$ In $8.4 \%$ of the patients, the manner of poisoning was unreported. One homicidal poisoning was reported. ${ }^{34}$

\section{Toxicokinetics}

Most of the studies reported an onset of symptoms within 3 hours. With oral ingestion, appearance of symptoms was earlier, and the recovery was delayed as compared to percutaneous exposure. ${ }^{37}$ The duration of action is short and the elimination half-life in serum is only 4 hours, the major terminal metabolite being 3-methyl-4aminobenzoic acid, which is excreted by the kidneys. ${ }^{1,7}$

\section{Dose-response Relationship}

The amount of poison consumed ranged from $63 \mathrm{mg}$ to $100 \mathrm{~g}$. Ten studies reported a dose of more than $12 \mathrm{~g}$. The proposed lethal dose of the toxin is $200 \mathrm{mg} / \mathrm{kg}^{34,44}$ Therefore, with an average adult weight of $60 \mathrm{~kg}$, a dose of $12 \mathrm{~g}$ is supposedly lethal. Death was reported in only two patients in the 10 studies with an intake of more than $12 \mathrm{~g}$ amitraz. The exact dose and clinical course was available only for one patient and the death was attributable to the poisoning itself as reported by Hu et al. ${ }^{36} \mathrm{~A} 53$-year-old female who had consumed $100 \mathrm{~g}$ of the poison and developed refractory torsades de pointes.

\section{Clinical Features}

The clinical characteristics of the poisoning cases reported are shown in Table 1. The toxic effects of the compound on various organs of the human body have been summarized below.

\section{Effects on the Nervous System}

CNS depression manifesting as sleepiness, drowsiness, or complete loss of consciousness depending on the dose of the toxin
Table 1: Frequencies of various clinical features described in amitraz poisoning ${ }^{1,3-5,7-12,22-43}$

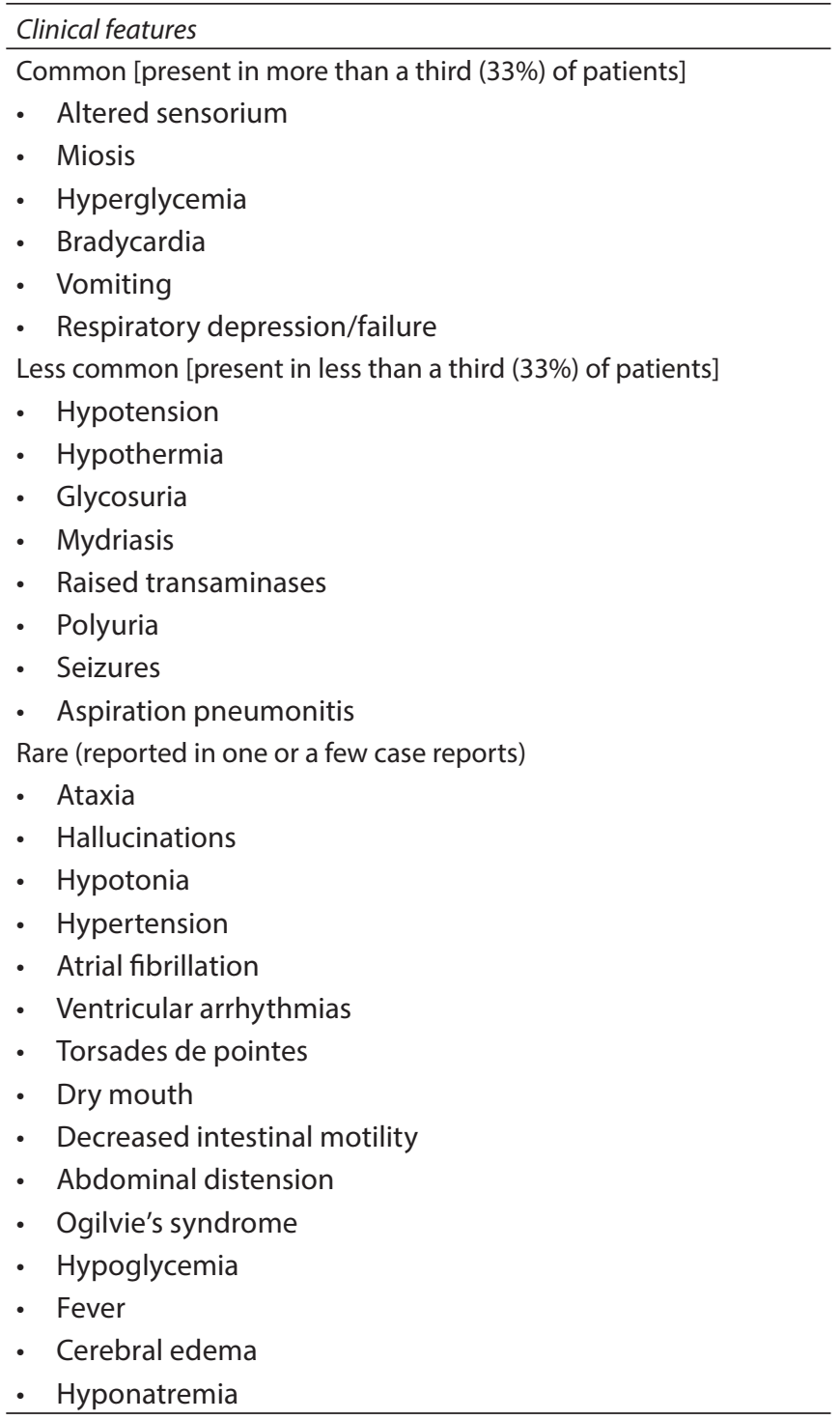

consumed $^{42}$ was the most common neurological abnormality. The duration of CNS depression had a positive correlation with the amount of amitraz taken. Most patients regained consciousness by 48 hours possibly due to the short elimination half-life of the toxin. Alternative causes should be looked for if altered sensorium persists beyond this duration. Cerebral edema in brain imaging was documented in two studies. ${ }^{9,24}$ Seizures occurred in $<33 \%$ of the cases.

Amitraz exposure caused constriction of pupils at lower doses but dilation at higher doses (Table 2). 4,12,13,20,25,26,31,34,35,37,42,45-52 The same patient can have both miosis and mydriasis at different times. Ataxia, hallucinations, and hypotonia were rarely reported neurological defects.

\section{Effects on the Cardiovascular System}

Cardiovascular manifestations occur mainly due to the stimulation of presynaptic $a_{2}$-adrenergic receptors (Table 2). ${ }^{12,45,47,48}$ Bradycardia was the most common cardiovascular manifestation observed in more than $33 \%$ of the patients. Hypotension occurred in a smaller 
Table 2: Systemic effects of amitraz and their underlying mechanisms $4,12,13,20,25,26,31,34,35,37,42,46-55,58$

\begin{tabular}{|c|c|}
\hline Effects & Mechanism \\
\hline $\begin{array}{l}\text { Altered sensorium (CNS } \\
\text { depression) }\end{array}$ & $\begin{array}{l}\text { Simulation of the central } a_{2} \text {-adrenergic } \\
\text { receptors and contributed by xylene } \\
\text { solvent }\end{array}$ \\
\hline Miosis & $\begin{array}{l}\text { Presynaptic } a_{2} \text {-adrenergic stimulation } \\
\text { (low doses) }\end{array}$ \\
\hline Mydriasis & $\begin{array}{l}\text { Postsynaptic } \mathrm{a}_{2} \text {-adrenergic } \\
\text { stimulation (at higher doses), atropine } \\
\text { administration }\end{array}$ \\
\hline Seizures & $\begin{array}{l}\text { Stimulation of the central } a_{2}^{-} \\
\text {adrenergic receptors }\end{array}$ \\
\hline Hyperglycemia & $\begin{array}{l}\text { Inhibition of insulin secretion and } \\
\text { stimulation of glucagon secretion }\end{array}$ \\
\hline Bradycardia & $\begin{array}{l}\text { Stimulation of the dorsal motor } \\
\text { nucleus of the vagal nerve through } \\
\text { presynaptic } a_{2} \text {-adrenergic agonist } \\
\text { action }\end{array}$ \\
\hline Hypotension & $\begin{array}{l}\text { Simulation of the central presynaptic } \\
a_{2} \text {-adrenergic receptors with } \\
\text { diminution of peripheral sympathetic } \\
\text { tone }\end{array}$ \\
\hline Respiratory depression & $\begin{array}{l}\text { Inhibition of response to } \mathrm{CO}_{2} \text { by direct } \\
\text { effect on respiratory center }\end{array}$ \\
\hline Hypothermia & Inhibition of prostaglandin synthesis \\
\hline Raised transaminases & $\begin{array}{l}\text { Reduced hepatic glutathione activity } \\
\text { by amitraz, although xylene may be a } \\
\text { potential cause }\end{array}$ \\
\hline Polyuria & $\begin{array}{l}\text { Decreased ADH secretion and } \\
\text { inhibition of its renal effect, hypergly- } \\
\text { cemia, and excessive fluid administra- } \\
\text { tion }\end{array}$ \\
\hline Vomiting & Due to the solvent \\
\hline
\end{tabular}

proportion of cases (Table 1). Arrhythmias including atrial fibrillation and ventricular arrhythmias responded to standard treatment. ${ }^{3,32}$ Fatal torsades de pointes was reported in one case. ${ }^{36}$

\section{Effects on the Gastrointestinal System and Liver}

Vomiting was reported in most of the patients. Asymptomatic transaminitis may occur usually with a normal bilirubin. Dry mouth, decreased intestinal motility, and abdominal distension ${ }^{5,21,25,34}$ were rarely reported. One case of Ogilvie's syndrome (acute colonic pseudo-obstruction) was also reported ${ }^{24}$ (Table 1).

\section{Effects on the Respiratory System}

Respiratory depression occurred in majority of the cases (Table 1) in the form of bradypnea, respiratory acidosis, or respiratory arrest due to direct effect of the poison. Aspiration pneumonia was also reported in a small proportion of patients.

\section{Effects on Metabolism and Homeostasis}

Hyperglycemia, a distinctive feature of this poisoning was observed in $50 \%$ of the patients. Hypoglycemia and glycosuria were rarely reported. Hypothermia occurred commonly while fever was rare. ${ }^{31,42}$ Polyuria may also occur.

Management was mainly supportive as there is no specific antidote and mainly depended on cardiovascular, respiratory, and CNS stability. Around 33\% of patients developed respiratory failure and $20 \%$ of them needed mechanical ventilation; however, most got extubated within 48 hours (within 24 hours in our case). Intravenous fluids and vasopressors/inotropes were administered as per the need. One debatable point in the treatment was the use of atropine. While majority of the literature states that atropine is effective precisely in symptomatic bradycardia and atrioventricular blocks, some authors believe that it can be used in bradycardia induced by other mechanisms such as amitraz toxicity.

\section{Discussion}

The results of this systematic review suggest that amitraz poisoning is not a widely reported intoxication. It has varying clinical manifestations and carries a good prognosis. Turkey reported a large proportion of cases of amitraz poisoning (15 articles, 220 cases). Six reports on amitraz poisoning have been published from India ${ }^{9-11,27,30,41}$ in the last 6 years. A large number of cases (69 patients) have been reported from South Africa. ${ }^{5}$ Toxic exposure in humans may occur by inhalation, ingestion, or by skin contact. Animal studies show that absorption from the gut occurs at a high rate. Amitraz concentrations are measurable in the plasma within 2 hours of ingestion., ${ }^{1,20}$ Amitraz is primarily metabolized rapidly in vivo to produce two metabolites: 2,4-dimethyl formanilide (BTS-27919) and an active metabolite $N^{\prime}$-(2,4-dimethylphenyl)$\mathrm{N}$-methyl-formamidine (BTS27271), resulting in a rapid onset of symptoms. ${ }^{6,736}$ BTS-27271 acts through the octopamine receptors in invertebrates; this mechanism is responsible for its insecticidal and acaricidal activities. In vertebrates, it acts mainly on the $a_{2}$-adrenergic receptor. It acts as an agonist on both pre- and postsynaptic $\mathrm{a}_{2}$-adrenergic receptors. ${ }^{42,55}$ Presynaptic receptor stimulation inhibits norepinephrine release, while stimulation of postsynaptic receptors leads to effects of $a_{1}$-stimulation. ${ }^{25,42}$ It also acts as a MAO inhibitor and an inhibitor of PGE2; however, the role of these actions in poisoning is unclear. Amitraz has been classified as a "possible" human carcinogen by the US EPA as it is shown to increase the risk of lymphoreticular malignancies and liver adenoma/carcinoma in mice. ${ }^{6}$ However, there are no reports of increased cancer risk in humans. Amitraz has been found to have teratogenic effect in frogs, ${ }^{56}$ but there is no human data.

The clinicians were unfamiliar with amitraz in $89 \%$ of the instances ${ }^{17}$ in a report from a poison information center. Recovering the poison container and discerning the active compound in the preparation should be encouraged among clinicians. Three most common features of this poisoning are altered sensorium, miosis, and bradycardia, which can often mislead physicians into diagnosing the patient with OPC poisoning. Features that point toward amitraz poisoning as opposed to OPC toxicity include presence of hyperglycemia, hypothermia, and reduced gastrointestinal motility. The absence of fasciculations and a hypersecretory state (salivation, lacrimation, perspiration, and diarrhea) also point against OPC poisoning. Smell of a solvent or a 'mothball-like' odor points toward amitraz poisoning, while a garlic-like smell is encountered with OPC poisoning. ${ }^{3,37,58}$ Serum cholinesterase levels are normal in amitraz poisoning, while these are often low in OPC poisoning. 5,27,41 Gas chromatography, mass spectrometry, and gas liquid chromatography have been used to detect the presence and measure the levels of amitraz and its metabolites in the serum and urine. ${ }^{1,3,36}$

There is no specific antidote for amitraz poisoning and treatment is mainly supportive. Monitoring of respiratory, cardiovascular, and CNS functions is rquired. ${ }^{12}$ The contaminated clothing should be 
removed and the skin should be washed with soap and water in case of skin exposure. To avoid the risk of aspiration, endotracheal intubation should be done early in unconscious patients.

Intravenous fluids and inotropes must be administered promptly in patients with shock. Clinical benefit of gastric lavage and activated charcoal has not been established. Organic solvents in the formulation increase the risk of aspiration if gastric lavage is attempted. ${ }^{13}$ Therefore, it should be performed only in cases of massive ingestion after endotracheal intubation. ${ }^{12,20}$ Activated charcoal is safer but the clinical benefit is again uncertain. Role of atropine is controversial. It has been shown to improve bradycardia in many of the patients, while in some patients, dopamine was used for the treatment of bradycardia. ${ }^{1,12,22,25}$ Atropine is effective only in patients with symptomatic bradycardia in amitraz poisoning and is usually not required for those with only asymptomatic bradycardia or miosis. Although there is no antidote, few animal studies have demonstrated that $\mathrm{a}_{2}$-adrenergic antagonists such as yohimbine and atipamezole can reverse most of the clinical and laboratory signs of amitraz poisoning. ${ }^{59,60}$ However, these drugs have not been used in human poisoning. Patients may sometimes receive pralidoxime for the mistaken diagnosis of OPC poisoning. Although naloxone has been used successfully for clonidine poisoning ( $a_{2}$-adrenergic agonist), it has proven to be ineffective in amitraz poisoning. ${ }^{61,62}$ Amitraz poisoning carries a good prognosis with a low case fatality rate. The probable reason for the low case fatality rate was that the compound was most commonly available in a $12.5 \%$ solution. The dose and route of exposure to the poison seem to be the most important factors affecting the clinical course and prognosis. Since there are no randomized trials, no conclusions can be drawn on the ideal management strategy for this poisoning. ${ }^{63-74}$

\section{Conclusion}

Amitraz poisoning occurs in either accidental or suicidal manner and is more common in children than adults. Majority of the cases have been reported from Turkey, though there has been a recent rise in the number of cases reported from South Africa and India. There is no specific antidote for this toxin till date. It has an excellent prognosis with supportive management.

\section{References}

1. Jorens PG, Zandijk E, Belmans $L$, et al. An unusual poisoning with the unusual pesticide amitraz. Hum Exp Toxicol 1997;16(10):600-601. DOI: $10.1177 / 096032719701601008$.

2. Gosselin RE, Hodge HC, Smith RP, et al. Clinical toxicology of commercial products. 5th ed., Baltimore: Williams and Wilkins; 1984. pp III-61-III-63.

3. Vucinic $S$, Jovanovic $D$, Vucinic $Z$, et al. A near-fatal case of acute poisoning by amitraz/xylene showing atrial fibrillation. Forensic Toxicol 2007;25(1):41-44. DOI: 10.1007/s11419-006-0019-x.

4. Jones RD. Xylene/amitraz: a pharmacologic review and profile. Vet Hum Toxicol 1990;32(5):446-448.

5. Veale DJ, Wium CA, Muller GJ. Amitraz poisoning in south Africa: a two year survey (2008-2009). Clin Toxicol (Phila) 2011;49(1):40-44. DOI: 10.3109/15563650.2010.542159.

6. Palmer Jr Jl, . Environmental Protection Agency 40 CFR Part 180

7. Bonsall JL, Turnbull GJ. Extrapolation from safety data to management of poisoning with reference to amitraz (a formamidine pesticide) and xylene. Hum Toxicol 1983;2(4):587-592. DOI: 10.1177/096032718300200403.

8. Elinav E, Shapira $Y$, Ofran $Y$, et al. Near-fatal amitraz intoxication: the overlooked pesticide. Basic Clin Pharmacol Toxicol 2005;97(3): 185-187. DOI: 10.1111/j.1742-7843.2005.pto_97399.x.
9. Shitole DG, Kulkarni RS, Sathe SS, et al. Amitraz poisoning-an unusual pesticide poisoning. J Assoc Physicians India 2010;58(5):317-319.

10. Sweta US, Agarwal A. Amitraz: an unfamiliar poisoning with familiar pesticide. J Anaesthesiol Clin Pharmacol 2013;29(3):420. DOI: 10.4103/0970-9185.117092.

11. Varma PC, Bhatt S, Bhat RY. Amitraz poisoning. Indian J Pediatr 2013;80(4):349-350. DOI: 10.1007/s12098-012-0772-2.

12. Yilmaz HL, Yildizdas DR. Amitraz poisoning, an emerging problem: epidemiology, clinical features, management, and preventive strategies. Arch Dis Child 2003;88(2):130-134. DOI: 10.1136/ adc.88.2.130.

13. Proudfoot AT. Poisoning with amitraz. Toxicol Rev 2003;22(2):71-74. DOI: 10.2165/00139709-200322020-00001.

14. Tavanaei M, Safari KS. Amitraz poisoning. Clin Toxicol 2010;48:303.

15. Jacob J, Schaeffer TH. Self-medication with amitraz for delusions of parasitosis: dermal exposure and a delayed presentation. Clin Toxicol 2011;49(6):563-564. 52 vanderbilt ave, new york, ny 10017 usa: informa healthcare.

16. Tavanaei M, Nematabad VA, Kamalabadi SS. Incidence of poisoning in Rafsanjan, Iran. Clin Toxicol 2012;50(4):295.

17. Veale DJ, Wium CA, Müller GJ. Toxicovigilance. I: a survey of acute poisonings in south Africa based on tygerberg poison information centre data. S Afr Med J 2013;103(5):293-297. DOI: 10.7196/SAMJ.6647.

18. Mutlu M, Cansu A, Karakas T, et al. Pattern of pediatric poisoning in the east Karadeniz region between 2002 and 2006: increased suicide poisoning. Hum Exp Toxicol 2010;29(2):131-136. DOI: 10.1177/0960327109357141.

19. Sabzghabaee AM, Eizadi-Mood N, Gheshlaghi F, et al. Is there a relationship between admission blood glucose level following acute poisoning and clinical outcome? Arch Med Sci 2011;7(1):81.

20. Garnier R, Chataigner D, Djebbar D. Six human cases of amitraz poisoning. Hum Exp Toxicol 1998;17(5):294. DOI: $10.1177 / 096032719801700515$.

21. Aydin K, Kurtoglu S, Poyrazoglu MH, et al. Amitraz poisoning in children: clinical and laboratory findings of eight cases. Hum Exp Toxicol 1997;16(11):680-682. DOI: 10.1177/096032719701601109.

22. Aydin K, Per H, Kurtoglu S, et al. Amitraz poisoning in children. Eur J Pediatr 2002;161(6):349-350. DOI: 10.1007/s00431-002-0945-5.

23. Agin $\mathrm{H}$, Calkavur $\mathrm{S}$, Uzun $\mathrm{H}$, et al. Amitraz poisoning: clinical and laboratory findings. Indian Pediatr 2004;41(5):482-485.

24. Aslan S, Bilge F, Aydinli B, et al. Amitraz: an unusual aetiology of Ogilvie's syndrome. Hum Exp Toxicol 2005;24(9):481-483. DOI: 10.1191/0960327105ht550cr.

25. Atabek ME, Aydin K, Erkul I. Different clinical features of amitraz poisoning in children. Hum Exp Toxicol 2002;21(1):13-16. DOI: 10.1191/0960327102ht207oa.

26. Avsarogullari L, Ikizceli I, Sungur M, et al. Acute amitraz poisoning in adults: clinical features, laboratory findings, and management. Clin Toxicol 2006;44(1):19-23. DOI: 10.1080/15563650500357545.

27. Batra B, Verma PK, Pramanik V, et al. Amitraz poisoning-familiar presentation, unfamiliar diagnosis. Anaesth Intensive Care 2012;40(2):363.

28. Beyaztas FY, Gursoy SI, Demirel YE, et al. Aspiration and death from amitraz-xylene poisoning. Middle East J Fam Med 2006;4:42.

29. Çaksen H, Odabaş D, Arslan Ş, et al. Report of eight children with amitraz intoxication. Hum Exp Toxicol 2003;22(2):95-97. DOI: 10.1191/0960327103ht333sr.

30. Chakraborty J, Nagri SK, Gupta AN, et al. An uncommon but lethal poisoning-amitraz. Australas Med J 2011;4(8):439. DOI: 10.4066/ AMJ.2011.777.

31. Demirel Y, Yilmaz A, Gursoy S, et al. Acute amitraz intoxication: retrospective analysis of 45 cases. Hum Exp Toxicol 2006;25(10): 613-617. DOI: 10.1177/096032706072472.

32. Doganay Z, Aygun D, Altintop L, et al. Basic toxicological approach has been effective in two poisoned patients with amitraz ingestion. Hum Exp Toxicol 2002;21(1):55-57. DOI: 10.1191/0960327102ht204cr.

33. Eizadi-Mood N, Sabzghabaee AM, Gheshlaghi F, et al. Amitraz poisoning treatment: still supportive? Iran J Pharm Res 2011;10(1):155. 
34. Ertekin V, Alp H, Selimoğlu MA, et al. Amitraz poisoning in children: retrospective analysis of 21 cases. J Int Med Res 2002;30(2):203-205. DOI: $10.1177 / 147323000203000215$.

35. Gursoy S, Kunt N, Kaygusuz K, et al. Intravenous amitraz poisoning. Clin Toxicol 2005;43(2):113-116. DOI: 10.1081/CLT-50412.

36. Hu SY, Hsu CL, Tsan YT, et al. Torsades de pointes in amitraz poisoning. Resuscitation 2010;81(3):366-367. DOI: 10.1016/ j.resuscitation.2009.11.009.

37. Kalyoncu M, Dilber E, Ökten A. Amitraz intoxication in children in the rural black sea region: analysis of forty-three patients. Hum Exp Toxicol 2002;21(5):269-272. DOI: 10.1191/0960327102ht241oa.

38. Kennel O, Prince C, Garnier R. Four cases of amitraz poisoning in humans. Vet Hum Toxicol 1996;38(1):28-30.

39. Leung VK, Chan TY, Yeung VT. AmitrazPoisioning in humans. J Toxicol Clin Toxicol 1999;37(4):513-514. DOI: 10.1081/CLT-100102523.

40. Mwita CC. Amitraz poisoning in a patient from rural Africa. J Case Rep 2012;2(2):39-41. DOI: 10.17659/01.2012.0014.

41. Rajesh NT, Pandian NS, Mathai J. Poisoning with amitraz, a veterinary drug, in an adolescent boy. Sri Lanka J Child Health 2014;43(1):55-56. DOI: 10.4038/sljch.v43i1.6664.

42. Ulukaya $\mathrm{S}$, Demirağ $\mathrm{K}$, Moral A. Acute amitraz intoxication in human. Intensive Care Med 2001;27(5):930-933. DOI: 10.1007/s001340100934.

43. Yaramis A, Soker M, Bilici M. Amitraz poisoning in children. Hum Exp Toxicol 2000;19(8):431-433. DOI: 10.1191/096032700682694215.

44. Dreisbach RH. Diagnosis and treatment. Handbook of poisoning. California: Lange Medical Publishing; 1977. p. 126.

45. Hsu WH, Kakuk TJ. Effect of amitraz and chlordimeform on heart rate and pupil diameter in rats: mediated by $\mathrm{a}_{2}$-adrenoreceptors. Toxicol Appl Pharmacol 1984;73(3):411-415. DOI: 10.1016/0041008X(84)90093-0.

46. Abu-Basha EA, Yibchok-Anun S, Hopper DL, et al. Effects of the pesticide amitraz and its metabolite BTS 27271 on insulin and glucagon secretion from the perfused rat pancreas: involvement of $a_{2}$ D-adrenergic receptors. Metabolism 1999;48(11):1461-1469. DOI: 10.1016/S0026-0495(99)90160-9.

47. Tsuchiya $\mathrm{Y}$, Hosokawa T, Kasuya $\mathrm{Y}$. Involvement of $\mathrm{a}_{2}$-adrenergic receptors in the vagal reflex-induced tracheal constriction. J Pharmacobiodyn 1990;13(1):30-35. DOI: 10.1248/bpb1978.13.30.

48. Robertson $\mathrm{HA}$, Leslie RA. Noradrenergic alpha2 binding sites in vagal dorsal motor nucleus and nucleus tractussolitarius: autoradiographic localization. Can J Physiol Pharmacol 1985;63(9):1190-1194. DOI: $10.1139 / y 85-195$.

49. Reynoldson JA, Cullen LK. Amitraz depresses cardiovascular responses to bilateral carotid occlusion. J Vet Pharmacol Ther 1996;19(1):22-26. DOI: 10.1111/j.1365-2885.1996.tb00003.x.

50. Maze M, Tranquilli W. Alpha-2 adrenoceptoragonistsDefining the role in clinical anesthesia. Anesthesiology 1991;74(3):581-605. DOI: 10.1097/00000542-199103000-00029.

51. Yim GK, Holsapple MP, Pfister WR, et al. Prostaglandin synthesis inhibited by formamidine pesticides. Life Sci 1978;23(25):2509-2515. DOI: 10.1016/0024-3205(78)90176-5.

52. Harvey PW, Cockburn A, Davies WW. Commentary on'an unusual poisoning with the unusual pesticide amitraz'with respect to the pharmacology of amitraz. Hum Exp Toxicol 1998;17(3):191. DOI: 10.1177/096032719801700312.

53. Folz SD, Kakuk TJ, Henke CL, et al. Clinical evaluation of amitraz as a treatment for canine demodicosis. Vet Parasitol 1984;16(3-4):335-341. DOI: 10.1016/0304-4017(84)90051-7.

54. Grossman MR. Amitraztoxicosis associated with ingestion of an acaricide collar in a dog. J Am Vet Med Assoc 1993;203(1):55-57.
55. Queiroz-Neto A, Zamur G, Goncalves SC, et al. Characterization of the antinociceptive and sedative effect of amitraz in horses. J Vet Pharmacol Ther 1998;21(5):400-405. DOI: 10.1046/j.13652885.1998.00150.x.

56. Osano O, Oladimeji AA, Kraak MH, et al. Teratogenic effects of amitraz, 2,4-dimethylaniline, and paraquat on developing frog (xenopus) embryos. Arch Environ Contam Toxicol 2002;43(1):42-49. DOI: 10.1007/s00244-002-1132-4.

57. Dadpour B, Forooghian M, Talebi M, et al. A case report of deep coma in a pregnant women with amitraz poisoning. Iran J Obstet Gynecol Infertil 2013;16(45):9-12.

58. Parrish A, Lancaster R. Does the nose know?:amitraz poisoning and olfaction. S Afr Med J 2012;102(4):223-224.

59. Hugnet C, Buronfosse F, Pineau X, et al. Toxicity and kinetics of amitraz in dogs. Heart 1996;2(3305):5.

60. Smith BE, Hsu WH, Yang PC. Amitraz-induced glucose intolerance in rats: antagonism by yohimbine but not by prazosin. Arch Toxicol 1990;64(8):680-683. DOI: 10.1007/BF01974698.

61. Nichols MH, King WD, James LP. Clonidine poisoning in Jefferson county, Alabama. Ann Emerg Med 1997;29(4):511-517. DOI: 10.1016/ S0196-0644(97)70225-7.

62. Schaffer DD, Hsu WH, Hopper DL. The effects of yohimbine and four other antagonists on amitraz-induced depression of shuttle avoidance responses in dogs. Toxicol Appl Pharmacol 1990;104(3):543-547. DOI: 10.1016/0041-008X(90)90176-U.

63. Bhartiya $M$, Hans $B$, Sundaray $S$, et al. Amitraz poisoning: the not so (un) common poisoning. Cureus 2019;11(8):e5438. DOI: 10.7759/ cureus.5438.

64. Dhadke S, Kantte V, Dhadke V, et al. Clinical profile of amitraz poisoning. J Assoc Physicians India 2019;67(4):55-57.

65. Wilson W, Murty S. Amitraz poisoning: the (un) common poisoning. J Emerg Trauma Shock 2018;11(2):140. DOI: 10.4103/JETS.JETS_33_17.

66. Dissanayake V, Dalka ET, Koh C, et al. A pilot study on the management and outcomes of self-poisoning in a rural ugandan emergency centre. Afr J Emerg Med 2018;8(1):25-28. DOI: 10.1016/j.afjem.2017. 11.002 .

67. Saseedharan S, Pathrose EJ, Madhav BV. A clinical conundrum called amitraz poisoning-A case report. Indian J Crit Care Med 2018;22(3):195. DOI: 10.4103/ijccm.IJCCM_241_17.

68. Basetty S, Mishra AK, Sathyendra S. Neurological effects of an unusual insecticide poison: amitraz. J Family Med Prim Care 2017;6(3):686. DOI: 10.4103/2249-4863.222044.

69. Shashidhara S, Mundkur SC, Hebbar SA, et al. Amitraz: a perpetual silent menace among children in developing countries-A case report. Pediatr Emerg Care 2019;35(9):e169-e171.

70. Nasa P, Juneja D. Acute pesticide ingestion managed with yohimbine as a rescue therapy. Indian J Crit Care Med 2016;20(12):739. DOI: 10.4103/0972-5229.195716.

71. Herath HM, Pahalagamage SP, Yogendranathan N, et al. Amitraz poisoning: a case report of an unusual pesticide poisoning in sri Lanka and literature review. BMC Pharmacol Toxicol 2017;18(1):6. DOI: 10.1186/s40360-016-0114-5

72. Jatav OP, Tiwari $D$, Lahariya $D$, et al. Amitraz poisoning treated successfully with atropine. J Assoc Physicians India 2016;64:82.

73. Dhooria S, Behera D, Agarwal R. Amitraz: a mimicker of organophosphate poisoning. BMJ Case Rep 2015;2015:bcr2015210296. DOI: 10.1136/bcr-2015-210296.

74. Dhooria S, Amitraz AR. An underrecognized poison: a systematic review. Indian J Med Res 2016;144(3):348. DOI: 10.4103/0971 5916.198723. 